\title{
MENGGALI KREATIVITAS REMAJA MELALUI PELATIHAN PROMOSI FILM INDIE DI DESA KRAMATMULYA, SOREANG, KABUPATEN BANDUNG
}

\author{
Rangga Saptya Mohamad Permana, Lilis Puspitasari, dan Sri Seti Indriani \\ Program Studi Televisi dan Film, Fakultas Ilmu Komunikasi, Universitas Padjadjaran \\ E-mail: rangga.saptya@unpad.ac.id
}

\begin{abstract}
ABSTRAK. Di Indonesia, konsep film indie adalah film-film yang tidak diproduksi oleh rumah produksi besar dan film yang mengeksprsikan idealisme pembuatnya tanpa tekanan dari pihak manapun. Film-film pendek yang dibuat atas dasar hobi dan kecintaan khalayak pada dunia film juga termasuk ke dalam film indie. Terkait dengan hal tersebut, sebagian besar remaja di Desa Kramatmulya, Soreang, Kabupaten Bandung, telah memiliki akses pengetahuan dalam bidang produksi film-film pendek. Para remaja yang pada umumnya berusia antara 17-19 tahun ini telah memiliki pengalaman memproduksi film, mulai dari tahap pra-produksi sampai tahap post-produksi. Hanya saja, mereka belum memiliki pengetahuan yang cukup mengenai sistem dan model promosi film indie. Tujuan dari dilaksanakannya program pelatihan ini adalah memberikan pengetahuan mengenai promosi film indie kepada para remaja tersebut, serta memotivasi mereka, agar kelak ketika mereka ingin mencoba untuk memperkenalkan hasil karya mereka pada khalayak, mereka telah memiliki bekal pengetahuan untuk melakukannya melalui media promosi yang tepat. Metode-metode yang digunakan dalam pelatihan ini antara lain metode komunikasi bermedia (audio-visual), metode ceramah, metode interaktif, metode pre-test dan post-test, metode simulasi, serta metode ice breaking. Hasil yang dicapai setelah pelatihan ini dilaksanakan adalah para peserta menjadi memiliki pemahaman yang lebih baik megenai model, teknik dan pemilihan media promosi film indie serta memiliki keinginan dan motivasi untuk dapat memperkenalkan sampai mempromosikan film-film pendek yang telah mereka hasilkan.
\end{abstract}

Kata Kunci: Kreativitas; Promosi; Film; Indie

\section{DIGGING YOUTH CREATIVITY THROUGH INDIE FILM PROMOTION TRAINING IN KRAMATMULYA VILLAGE, SOREANG, BANDUNG REGENCY}

\begin{abstract}
In Indonesia, indie films are not produced by large production houses. These films express the idealism of the maker without any pressure from others. Short films made on the basis of hobbies and society's passion of films are also included in indie films. Related to that, most teenagers aged 17-19 years old in Kramatmulya Village, Soreang, Bandung Regency, have had access to knowledge in the field of short films productions. The teenagers have experienced in producing films, from the pre-production stage to the post-production stage. It's just that, they don't have enough knowledge about indie film promotion systems and models. The purpose of this training program was to provide knowledge about indie film promotion to the teenagers, and motivate them, so that later when they want to try to introduce their work to the public, they will have knowledge to do it through the right promotional media. The methods used in this training include media communication methods (audio-visual), lecture methods, interactive methods, pre-test and post-test methods, simulation methods, and ice breaking methods. The results achieved after this training was to have the participants a better understanding of the models, techniques and selection of indie film promotion media the desire and motivation to be able to introduce and promote their short films.
\end{abstract}

Key words: Creativity; Promotion; Film; Indie

\section{PENDAHULUAN}

Pengertian film independent atau film indie pada intinya adalah film yang diproduksi di luar major label, serta tidak dibuat untuk tujuan komersial; sehingga cenderung bebas dari pengawasan lembaga sensor dan tuntutan pasar. Sebagai kebalikan dari perusahaanperusahaan film besar (major label), sebut saja (jaringan) bioskop Cinema XXI, CGV Blitz, Cinemaxx, dan Platinum Cineplex, sebuah perusahaan pembuat film indie tentu saja terlihat kecil. Anggaran yang terbatas membuat perusahaan-perusahaan ini jarang memakai aktor/aktris besar. Dengan minimnya anggaran, justru para sineas film indie memutar otak dan "memaksa" kreativitas mereka menembus batas-batas mainstream.

"Kekerdilan" film indie justru menjadi keuntungan bagi banyak pembuat film, mereka mampu untuk mengambil risiko dan membuat film di luar mainstream. Segmen film indie yang biasanya diperuntukkan bagi khalayak yang lebih kecil mampu menjadi lebih "gelap", lebih subversif, dan bahkan secara politis tidak benar, karena mereka tidak bergantung pada sejumlah besar orang untuk melihat mereka agar mendapatkan banyak keuntungan. Dengan munculnya gerakan film indie, minat pada jenis film yang lebih beragam meningkat, yang lagi-lagi menciptakan lebih banyak kesempatan bagi siapa saja untuk terlibat dalam bisnis film (Moore, 2011: 13).

Gerakan film indie tumbuh kuat; dengan meningkatnya permintaan untuk konten, semakin banyak pembuat film diberi kesempatan untuk bekerja dan mendistribusikan proyek-proyek mereka. Festival film tumbuh lebih dan lebih populer, bukan hanya sebagai tempat di mana penggemar film akan berkumpul untuk menyaksikan film, tetapi juga sebagai pasar untuk menaikkan pamor para sineas indie. Pemenang penghargaan film pendek (dan para pembuat film-nya) dapat memimpikan untuk tur lintas negara, dan kadang-kadang dunia, dengan sebuah film pendek, kadang-kadang dengan biaya yang 
dibayarkan oleh festival film yang mereka menangkan (Moore, 2011: 14).

Di Indonesia sendiri telah banyak bermunculan festival film yang telah rutin dilangsungkan setiap tahun, baik itu dalam lingkup nasional maupun regional. Sebut saja Festival Film Indonesia, Festival Film Bandung, Festival Film Dokumenter Yogyakarta, Hello;Fest Motion Art Festival, Q Film Festival, Malang Film Festival, JogjaNetpac Asian Film Festival, Festival Film Purbalingga, dan Coordination for Film Festival in Indonesia (Coffie). Seperti yang telah disebutkan oleh Moore di atas, ajang festival film di Indonesia ini menjadi sarana dan etalase yang tepat bagi para sineas film indie untuk menaikkan reputasi mereka; sekaligus juga sebagai ajang perkenalan dan pelestarian karya-karya mereka.

Sebelum era internet, para pelaku indie dapat berekshibisi melalui festival, program ekshibisi acara komunitas, serta berbagai kineklub (komunitas film) yang tersebar di kampus dan berbagai tempat, contohnya adalah Kineforum di Taman Ismail Marzuki, Jakarta. Kini mereka bisa menggunakan berbagai platform internet seperti Kineria, Viddsee, Youtube, Vimeo, bahkan bisa melalui aplikasi seperti Instagram. Merupakan nilai tambah sebuah film indie, jika penayangan perdananya terjadi di sebuah festival. Apalagi festival tertentu memang memberi syarat film tak pernah diputar di media/tempat lain sebelumnya.

Berkaitan dengan festival film, Suzanne Lyons mengatakan bahwa sebaiknya para pembuat film (sineas) indie mencari peluang memasukkan karya-karya mereka ke festival-festival film yang sesuai dengan genre filmnya. Festival film juga membuka kesempatan para sineas indie untuk bertemu para pembeli film dan sineas-sineas lain yang lebih berpengalaman, di mana pertemuan tersebut dapat dijadikan ajang bertukar pikiran dan informasi mengenai manajemen, produksi, maupun promosi film. Seperti yang tertuang dalam kutipan berikut ini:

“..we also keep our eyes open for other festivals that were a good fit for our genre. It's great press and an excellent place to meet buyers if you're self distributing, and the networking you'll be doing is well worth the time and effort. Really prepare for the festival in advance and talk to other producers who are old pros with festivals and get some advice and suggestions from them before you go" (Lyons, 2012: 212).

Namun dalam kesempatan lain, Elliott Kanbar memiliki pandangan lain mengenai festival film, karena ia berpandangan bahwa kini para sineas sebaiknya tidak terlalu bergantung pada festival film. Seperti yang tertuang dalam pernyataan berikut ini:

"Festival are no longer filled with film buyers falling in love with your film and offering you all kinds of great deals. Chances are you will not receive any offers, and you'll have wasted a great deal of money in attending.
If elevating your self-esteem is vital, then, $O K$, send your film to one or two of the major festivals. It may make you feel better and may even add a bit of prestige to your film. But don't count on it to help you pay back your investors" (Kanbar, 2013: 29).

Faktanya, tidak semua film indie mendapatkan kesempatan untuk tampil di festival-festival film. Memang, ada beberapa film indie yang didistribusikan via home video, TV kabel, atau internet (misalnya menggunakan website berbasis pemutaran video seperti Youtube). Gregory Bernstein (2015: 270) memaparkan pendapat menariktentang distribusifilmindie. Bernsteinmengatakan bahwa langkah pertama dalam mendistribusikan film indie adalah dengan self-distribution dengan teknik 'four-wall'. Sineas dapat menyewa sebuah home theater dan membuka semacam "bioskop mini" untuk menarik penonton. Penonton tersebut yang menjadi alat marketing filmnya; jika filmnya menarik dan memberikan kesan kuat bagi penonton, biasanya penonton akan menyebarkannya melalui status di akun sosial media mereka. Jika film menjadi viral, dan jika sang sineas beruntung, filmnya tersebut akan diperhatikan oleh pengulas film, yang nantinya akan mengundang minat para distributor film.

Self-distribution juga bisa dilakukan via internet. Terdapat beberapa website yang dapat dipakai untuk mendistribusikan film indie--dan biasanya berbiaya relatif rendah - contohnya lewat website tribber.com dan tunecore.com. Jika film indie dipasarkan dalam bentuk DVD, website CreateSpace.com dan Redbox bisa digunakan. Sineas indie Indonesia seringkali menggunakan kanal-kanal di internet untuk mendistribusikan film-film indie mereka, sebut saja via Kineria, ID Film Center, Viddsee, Buttonijo, Layaria, dan www.nonton.com.

Di zaman yang serba digital, online marketing melibatkan banyak pilihan. Pilihan pertama dan yang paling umum, produser dan distributor dapat memasarkan filmnya melalui acara $T V W e b$ dan memakai media sosial. Website dapat dikelola secara sederhana; di mana melalui situs-situs tersebut, khalayak dapat menonton trailer film dan mendapatkan informasi mengenai para aktor/ aktris dan para kru. Produser dan distributor juga dapat memasarkan fimnya melalui iklan online dalam website yang sering dikunjungi. Komponen yang muncul dari online marketing adalah untuk memanfaatkan jejaring sosial dan merangsang efek viral (Ulin, 2014: 550). Dengan kata lain, pemanfaatan media sosial semaksimal mungkin.

Menurut Nasrullah (2015: 11), media sosial adalah medium di internet yang memungkinkan pengguna merepresentasikan dirinya maupun berinteraksi, bekerja sama, berbagi, berkomunikasi dengan pengguna lain, dan membentuk ikatan sosial secara virtual. Pemilihan media sosial sebagai salah satu media promosi film indie sejalan dengan karakteristik media sosial itu sendiri. Setidaknya ada dua karakteristik media sosial yang membuat new 
media ini dimanfaatkan untuk banyak hal, yakni konten yang dapat ditentukan oleh pengguna (user generated content/UGC) serta sebagai media untuk menyebarkan informasi/konten secara cepat dan mudah (share/sharing).

Berkaitan dengan media sosial, Tuten (dalam Lipschultz, 2015: 17) mengatakan bahwa media sosial mengacu pada komunitas online yang partisipatif, aktif, dan dinamis. Komunitas ini memungkinkan para anggotanya untuk menghasilkan, mempublikasikan, mengontrol, mengkritisi, membuat peringkat, dan berinteraksi dengan konten online. Media sosial hadir dan berkembang seiring dengan perkembangan smartphone. Media sosial dapat diakses di manapun dan kapanpun melalui smartphone, selama jaringan internet tersedia. Di balik kepraktisan dan efisiensinya, media sosial juga dapat menjadi pedang bermata dua, di mana khalayak dapat menyebarkan pesanpesan HOAX dengan cepat dan mudah melalui media sosial.

Mauludin, dkk. (2017) mengamini pendapat tersebut. Menurut mereka, media sosial saat ini tidak hanya dipandang sebagai ajang bersosialisasi di dunia maya semata, namun sudah berkembang menjadi media tempat aktualisasi diri dan membagikan pemikiran-pemikiran kita kepada khalayak. Bahkan, dahsyatnya kekuatan media sosial dapat memengaruhi opini publik para pengguna media sosial tersebut. Oleh karena itu, media sosial juga dapat dijadikan media propaganda negatif untuk sebuah kepentingan tertentu.

Salah satu media sosial yang bukan berbasis video (misalnya Youtube) yang paling tepat digunakan sebagai media promosi film indie adalah Facebook. Meskipun tergolong salah satu media sosial "old school" atau telah lama muncul, tetapi Facebook masih terhitung media sosial yang efektif dalam mempromosikan dan memviralkan segala sesuatu. Berbagai fitur yang disediakan oleh Facebook tergolong paling lengkap diantara media sosial lain, karena melalui Facebook, kita bisa membagikan tulisan, gambar/foto, lagu, video, hingga fitur interaksi langsung melalui Facebook Live. Hal ini sejalan dengan pemikiran Kanbar mengenai Facebook dalam konteks promosi film, seperti yang ia utarakan berikut ini:

"To most, Facebook is considered the ultimate social network. It is briliantly enginereed to be the ideal way for people to keep in touch with friends and family, to exchange photos and the latest news. So, why consider advertising your film on Facebook? Why is this network the sleeping giant? Because Facebook is the largest social network today, with close to one billion users. By the end of 2013, the number of users will most likely be two billion. And, most importantly, Facebook maintains a profile of each user. This enables advertisers to target their ads to users in such categories as age, occupation, sex, location, education, interest, political views, and relationships. Even if you are trying to reach one relatively small group, such as butterfly collectors, access to a pool of one billion users means you'll probably end up with thousands of people in this category. This is simply awesome" (Kanbar, 2013: 91-92).

Di era digital seperti sekarang, platform TV digital juga menjadi salah satu media yang paling banyak dipilih oleh para produser film untuk mempromosikan dan menjadi media eksibisi dari karya-karyanya. Platform ini mengandalkan teknologi streaming untuk menyiarkan program-programnya. Ada dua macam streaming, yakni streaming audio dan video (Fachruddin, 2014: 201). Kini media streaming menjadi populer, yaitu sebuah teknologi yang memungkinkan distribusi data audio, video dan multimedia secara real-time melalui internet. Media streaming merupakan pengiriman media digital (berupa video, audio dan data) agar bisa diterima secara terusmenerus (stream). Data tersebut dikirim dari sebuah server aplikasi dan diterima serta ditampilkan secara real-time oleh aplikasi pada gawai penggunanya.

Untuk paltform TV digital, Netflix menjadi salah satu media paling eksklusif untuk mempromosikan dan meyiarkan film. Netflix juga merupakan salah satu platform yang banyak digemari oleh khalayak untuk menonton film-film dan serial-serial terbaru, khususnya film-film Hollywood dan serial-serial produksi Amerika Serikat. Netflix menjadi salah satu platform streaming yang paling banyak penggunanya di seluruh dunia. Seperti yang tertuang dalam kutipan berikut ini:

"With more than 36 million subscribers in forty different countries, Netflix is one of the leading subscriptions streaming services in the world, especially in the United States (HBO, for comparison's sake, only boasts 27,8 million subscribers). In the past few years, it's also emerged as a potentially serious player in the game for original content, shelling out $\$ 100$ million for its first outing, a two-season commitment for an adaptation of the BBC miniseries House of Cards, which premiered to critical praise on February 1, 2013'" (Curtin, et.al., 2014: 132).

Selain memiliki banyak pengguna, keunggulan lain dari Netflix ialah ketersediaan platform digital yang dapat diakses dari berbagai media digital, tidak hanya melalui media massa konvensional seperti TV, tetapi pengguna juga dapat mengakses konten-konten Netflix melalui personal computer (PC), tablet, bahkan Xbox. Hal ini sejalan dengan pernyataan yang disampaikan oleh Jeffrey Ulin berikut ini:

"Netflix streaming grew not on TV, but watching via PCs. Netflix, in fact, succeeded by trying to make the application ubiquitously availableNetflix didn't care whether you were accessing your account by your computer, over an Xbox, via a tablet, or through a box" (Ulin, 2014: 396). 
Paparan di atas adalah kondisi film indie di Indonesia dan beberapa media yang dapat digunakan untuk mempromosikan film-film indie maupun filmfilm komersial. Berdasarkan paparan di atas, penulis berpendapat bahwa kini banyak sekali media, teknik, dan strategi yang dapat digunakan untuk mempromosikan sebuah film, termasuk di dalamnya film-film indie. Kini yang harus menjadi perhatian adalah seberapa kreatif seorang sineas dalam mencari peluang dan menggunakan media-media yang ada untuk mempromosikan film mereka.

Film-film pendek yang diproduksi atas dasar hobi dan sarana ekspresi seorang sineas biasanya tidak diproduksi dengan biaya besar- dengan kata lain, diproduksi dengan biaya dan alat-alat seadanya. Sebagai media ekspresi sineas, mereka juga biasanya tidak/belum berpikir untuk langkah selanjutnya; yaitu mempromosikan film mereka. Padahal, jika film mereka berkualitas, terutama dari segi konten, langkah selanjutnya adalah berupaya untuk mengemas film tersebut agar dikenal oleh khalayak luas; sampai pada memeroleh keuntungan secara finansial.

Berangkat dari asumsi tersebut, penulis melihat bahwa para remaja di Desa Kramatmulya, Soreang, Kabupaten Bandung, memiliki potensi untuk menjadikan film-film hasil karya mereka untuk lebih dikenal masyarakat. Para remaja ini telah memiliki pengetahuan yang cukup di bidang produksi film, mulai dari tahap praproduksi sampai pada tahap post-produksi. Hanya saja, mereka belum memiliki pengetahuan mengenai strategi dan teknik promosi film. Oleh karena itu, penulis telah melakukan sebuah pelatihan mengenai promosi film, khususnya promosi film indie, yang bertujuan untuk memberikan pemahaman mengenai promosi film indie kepada para remaja tersebut, serta memotivasi mereka, agar kelak ketika mereka ingin mencoba untuk memperkenalkan hasil karya mereka pada khalayak, mereka telah memiliki bekal pengetahuan untuk melakukannya melalui media promosi yang tepat.

\section{METODE}

Kegiatan pelatihan promosi film indie di Desa Kramatmulya, Soreang, Kabupaten Bandung yang telah dilakukan ini, dengan mempertimbangkan materi pelatihan dan para remaja berusia 17-19 tahun sebagai peserta pelatihan, masalah yang berkembang dan lingkungan yang mendukung, dalam pelaksanaannya menggunakan beberapa metode berikut, yaitu: (1) Metode komunikasi bermedia (audio-visual); (2) Metode ceramah; (3) Metode interaktif/dialog; (4) Metode pre-test dan post-test; (5) Metode simulasi; dan (6) Metode ice breaking.

Metode komunikasi bermedia dilakukan dengan menayangkan materi mengenai pengetahuan umum yang berkaitan dengan penggalian ide untuk diangkat menjadi sebuah prduksi film indie, film indie di Indonesia, konsepkonsep dalam film indie, strategi pemilihan media promosi film indie, sampai dengan model-model komunikasi pemasaran film indie di Indonesia menggunakan media audio visual. Metode ini lebih menarik karena disampaikan dengan video pendek, ilustrasi musik, dan kombinasi gambar serta poster yang menarik, sehingga materi-materi lebih mudah diterima oleh para peserta yang notabene merupakan generasi millenial yang telah terbiasa bersentuhan dengan konten-konten audio visual melalui gawai yang mereka miliki.

Metode ceramah dilakukan dengan memberikan wawasan umum kepada para peserta mengenai strategi promosi film indie dengan menggunakan berbagai media, baik itu media konvensional maupun media digital. Selain itu, pemateri juga memotivasi dan berusaha untuk menimbulkan keinginan para peserta pelatihan untuk mencoba memperkenalkan dan mempromosikan karyakarya film mereka yang selama ini hanya mereka simpan untuk koleksi pribadi.

Metode interaktif/ dialog dilakukan dengan memberikan kesempatan kepada para peserta untuk menyampaikan pertanyaan seputar materi yang belum atau tidak dipahaminya, atau pertanyaan di luar materi tapi masih relevan dengan topik yang disampaikan. Para peserta juga dapat menceritakan pengalaman mereka yang berkenaan dengan produksi film mereka, mulai dari tahap pra-produksi sampai post-produksi. Menurut Roestiyah (dalam Susanti \& Permana, 2017), metode dialog merupakan salah satu teknik pengajaran untuk memberikan motivasi kepada para siswa (dalam hal ini para peserta pelatihan) agar aktif pemikirannya untuk bertanya ketika guru (dalam hal ini pemateri) mengajukan pertanyaan.

Metode pre-test dan post-test dilakukan dengan memberi kuesioner tentang pengetahuan dan sikap para peserta terhadap program pelatihan promosi film indie sebelum dan sesudah materi pelatihan disampaikan untuk mengetahui efektivitas kegiatan pelatihan yang dilakukan.

Metode simulasi dilakukan dengan cara mengajak para peserta pelatihan untuk mencari festival-festival film nasional yang dirasa cocok dengan genre film yang telah mereka produksi, membuat akun-akun di beberapa media sosial (Facebook, Youtube, Twitter, Path, dan Instagram) di mana di dalamnya terdapat video trailer film mereka atau tautan menuju sinopsis dan trailer film mereka, hingga screening/pemutaran film-film karya mereka dan saling memberikan kritik serta masukan terhadap filmfilm tersebut.

Metode ice breaking dilakukan dalam sesi perkenalan dan pertengahan sesi pelatihan dengan para peserta agar mereka merasa tertarik dan bersemangat mengikuti jalannya kegiatan sampai program pelatihan berakhir. Alhasil, para peserta pun sangat antusias dengan kedatangan kami dalam memberikan pelatihan ini.

\section{HASIL DAN PEMBAHASAN}

Pelatihan promosi film indie ini bertujuan untuk memberikan pemahaman mengenai promosi film indie kepada para peserta, serta memotivasi mereka, agar kelak ketika mereka ingin mencoba untuk memperkenalkan 
hasil karya mereka pada khalayak, mereka telah memiliki bekal pengetahuan untuk melakukannya melalui media promosi yang tepat. Penulis melihat para remaja di Desa Kramatmulya, Soreang, Kabupaten Bandung memiliki potensi di bidang film indie jika dikembangkan secara positif.

Film-film yang tercipta berkat kebebasan pikiran dan perasaan pembuatnya tanpa ada tekanan dari pihak lain serta merupakan perwujudan eksistensi pembuatnya bisa masuk ke dalam kategori film indie. Film-film indie juga biasanya merupakan film yang berada dalam jalur non-mainstream; film-film yang berada di luar arus utama. Para remaja di Desa Kramatmulya, Soreang, Kabupaten Bandung telah menciptakan beberapa film pendek yang didasari atas kecintaan mereka pada film. Akan terasa mubazir apabila film-film pendek karya mereka tidak dikenal oleh masyarakat luas. Oleh karena itu, penulis dan tim PPM Universitas Padjadjaran memiliki inisiatif untuk membuat program pelatihan promosi film indie ini.

Terdapat beberapa media/teknik/strategi untuk mempromosikan film-film indie, baik itu menggunakan cara konvensional maupun penggunaan platform media digital. Festival-festival film, pembentukan komunitas film dan ruang putar alternatif, press screening, serta roadshow/gerilya dapat dipilih sebagai cara konvensional untuk mempromosikan film-film indie. Sedangkan penggunaan platform media digital terwujud dalam promosi menggunakan media sosial, website eksibisi film, dan platform TV digital. Setiap cara/media memiliki keuntungan dan kerugiannya masing-masing, tergantung pada genre, pemilihan waktu dan biaya yang harus dikeluarkan dalam konteks promosi film.

Penulis beserta tim PPM Universitas Padjadjaran juga telah mencetak sepuluh buah poster yang diberikan kepada peserta pelatihan dan satu poster ukuran besar ditempel di tempat pelatihan dilangsungkan. Selain berperan sebagai media komunikasi luar ruang, poster ini juga dibuat dengan tujuan sebagai alat attention getter dan pengingat para peserta pelatihan khususnya dan pada masyarakat Desa Kramatmulya pada umumnya. Poster ini juga kami berikan di sesi penutup pelatihan kepada perwakilan peserta pelatihan.

Pada awal kegiatan, setelah para peserta mengisi daftar hadir, tim PPM langsung memberi mereka lembar pre-test untuk diisi. Hal ini dilakukan dengan tujuan untuk mengukur pengetahuan para peserta pelatihan mengenai film indie secara umum dan media-media promosi filmnya. Setelah seluruh peserta mengisi pre-test, kegiatan penyuluhan dilanjutkan dengan ice breaking oleh pemateri kegiatan pelatihan, yaitu Sri Seti Indriani, S.IP., M.Si. Ice breaking ini dilakukan dengan tujuan agar para peserta rileks dan siap menerima materi-materi pelatihan yang diberikan oleh para pemateri pelatihan.

Setelah pembukaan dan ice breaking selesai, kegiatan pelatihan dilanjutkan dengan presentasi materi pelatihan promosi film indie menggunakan media audio visual yang di dalamnya juga berisi video pendek alur promosi film indie disertai ilustrasi musik yang menarik. Materi pelatihan ini menampilkan konten pemahaman film indie secara umum, perbedaan konsep film indie di Indonesia dan di Amerika Serikat, sampai strategistrategi pemilihan media/teknik promosi film indie dalam tataran praktis. Penyampaian materi-materi presentasi ini dilakukan dengan metode ceramah dan diakhiri dengan sesi tanya-jawab/interaktif. Sesi presentasi ini diakhiri dengan sharing pengalaman para peserta pelatihan dalam produksi fim-film pendek mereka, mulai dari tahap praproduksi sampai post-produksi.

Dengan berakhirnya sesi presentasi, kegiatan pelatihan berlanjut pada sesi simulasi. Sesi simulasi dilakukan dengan cara mengajak para peserta pelatihan untuk mencari festival-festival film nasional yang dirasa cocok dengan genre film yang telah mereka produksi, membuat akun-akun di beberapa media sosial (Facebook, Youtube, Twitter, Path, dan Instagram) di mana di dalamnya terdapat video trailer film mereka atau tautan menuju sinopsis dan trailer film mereka, hingga screening/pemutaran film-film karya mereka dan saling memberikan kritik serta masukan terhadap film-film tersebut. Untuk screening dan festival film, diharapkan para remaja di Desa Kramatmulya, Soreang, Kabupaten Bandung ini dapat mengadakannya setiap tahun sehingga menjadi ajang aktualisasi diri sekaligus menjadi event tahunan untuk mempromosikan film-film yang telah mereka hasilkan. Sebelum sesi simulasi dimulai, pemateri memberikan ice breaking dengan tujuan untuk menyegarkan kembali pikiran para peserta pelatihan setelah menyelesaikan sesi presentasi dan tanya jawab.

Setelah sesi simulasi selesai, sebagai sesi penutup, penulis beserta tim PPM selaku penyelenggara kegiatan pelatihan memberikan kenang-kenangan berupa sepuluh buah poster yang diberikan untuk para remaja di Desa Kramatmulya. Poster ini diterima secara simbolik oleh perwakilan peserta pelatihan. Poster dibuat dengan tujuan sebagai media komunikasi luar ruang sekaligus sebagai "penggugah" dan pengingat pada para sineas muda Desa Kramatmulya terhadap promosi film indie. Poster ini juga diharapkan dapat memotivasi para sineas muda di Desa Kramatmulya untuk memperkenalkan dan mempromosikan karya-karya mereka kepada masyarakat luas.

Sebelum kegiatan pelatihan benar-benar ditutup, tim PPM membagikan lembar post-test kepada para peserta dengan tujuan untuk mengetahui tingkat pengetahuan dan sikap para peserta terhadap promosi film indie setelah mereka mendapatkan materi-materi pelatihan. Ternyata setelah lembar pre-test dan post-test-nya selesai diolah, hasil test sebagian peserta penyuluhan secara kognitif mengalami peningkatan (menunjukkan adanya peningkatan pemahaman) dan memiliki keinginan untuk mempromosikan film indie yang telah mereka hasilkan. Tim PPM juga membagikan kuesioner evaluasi pelatihan; 
dari kuesioner evaluasi terlihat bahwa peserta cenderung menilai positif, baik dalam konteks materi pelatihan maupun cara penyampaian pemateri.

Setiap individu dalam tim pelaksana kegiatan ini merupakan individu-individu unggulan dengan kredibilitas yang baik. Keahlian yang dimiliki tersebut tentu saja mampu memberikan kontribusi yang maksimal dalam pelaksanaan pelatihan ini. Adapun hasil yang dicapai dalam kegiatan Pengabdian Pada Masyarakat (PPM) di Desa Kramatmulya, Soreang, Kabupaten Bandung ini adalah:

- Warga Desa Kramatmulya umumnya dan khusunya para peserta pelatihan secara kognitif memiliki pemahaman yang lebih baik mengenai promosi film indie. Mereka memiliki pengetahuan mengenai cara mempromosikan film indie melalui media promosi dan teknik promosi film indie yang tepat berdasarkan metode-metode yang telah diberikan oleh para pemateri pelatihan.

- Warga Desa Kramatmulya umumnya dan khusunya para peserta pelatihan secara afektif memiliki keinginan dan motivasi untuk mempromosikan film-film pendek yang telah mereka hasilkan menggunakan metode-metode yang telah diberikan oleh para pemateri pelatihan. Misalnya saja mendaftarkan film pendek mereka pada festival film lokal yang diselenggarakan di Bandung, membuat komunitas film remaja Kramatmulya sekaligus mengadakan sesi screening (pemutaran) film secara rutin dengan mengundang pula para sineas lokal dan calon investor, hingga menggunakan media sosial untuk mempromosikan film mereka.

\section{SIMPULAN}

Berdasarkan hasil kegiatan Pelatihan Promosi Film Indie di Desa Kramatmulya, Soreang, Kabupaten Bandung yang telah dilakukan, simpulan yang dapat diambil dari kegiatan ini adalah sebetulnya para peserta pelatihan ini telah memiliki pengetahuan dan kemampuan yang cukup dalam hal produksi film, mulai dari tahap praproduksi (pembentukan tim produksi, riset kebutuhan film, pembuatan script, dan lain-lain) sampai tahap postproduksi (editing audio visual). Hanya saja, para peserta belum memiliki pengetahuan dan motivasi yang cukup dalam hal memperkenalkan serta mempromosikan karya-karya mereka pada masyarakat luas. Diperlukan pengetahuan, pemahaman, dan motivasi kepada para peserta pelatihan terkait promosi film mereka. Kegiatan pelatihan ini dapat menjadi dasar munculnya kreativitas para peserta pelatihan dalam memilih media dan teknikteknik promosi film indie dengan melihat kesempatan dan peluang berdasarkan situasi dan kondisi yang terjadi.

Berdasarkan paparan di atas, kegiatan pelatihan ini bisa dikatakan sukses, karena selama dan setelah pelatihan berlangsung, para peserta pelatihan sangat antusias dalam mengikuti materi-materi yang diberikan oleh para pemateri. Selain berkembangnya pemahaman para peserta mengenai cara promosi film indie sesuai dengan metode-metode yang telah diberikan pemateri, mereka juga menjadi semakin termotivasi untuk dapat memperkenalkan dan mempromosikan film-film pendek karya mereka. Promosi film indie yang dimulai dari pemahaman mengenai konsep-konsep dasar promosi film indie sampai pada teknik pemilihan media promosi film indie secara tepat yang diberikan oleh para pemateri pelatihan telah dapat mereka serap secara kognitif dan dilakukan dalam tataran psikomotorik melalui simulasi promosi film indie bersama para pemateri.

\section{DAFTAR PUSTAKA}

Bernstein, G. (2015). Understanding the Business of Entertainment: The Legal and Business Essentials All Filmmakers Should Know. Burlington: Focal Press.

Curtin, M., Holt, J., \& Sanson, K. (2014). Distribution Revolution: Conversations About The Digital Future of Film and Television. Oakland: University of California Press.

Fachruddin, A. (2014). Dasar-Dasar Produksi Televisi: Produksi Berita, Feature, Laporan Investigasi, Dokumenter, dan Teknik Editing. Jakarta: Kencana.

Kanbar, E. (2013). You Finally Finished Your Film. Now What?: How to Distribute Your Film Successfully and Economically in a Very Tough Market. San Francisco: Council Oak Books.

Lipschultz, J.H. (2015). Social Media Communication. New York: Routledge.

Lyons, S. (2012). Indie Film Producing: The Craft of Low Budget Filmmaking. Waltham: Focal Press.

Mauludin, M.A., Alim, S., \& Sari, V.P. (2017). Cerdas dan Bijak dalam Memanfaatkan Media Sosial di Tengah Era Literasi dan Informasi: Studi Kasus di Kecamatan Cilaku Kabupaten Cianjur Propinsi Jawa Barat. Dharmakarya, 6 (1), 1-4.

Moore, J. (2011). Short Film Distribution: Film Festivals, The Internet, and Self-Promotion. Dulles: Mercury Learning.

Nasrullah, R.(2015).Media Sosial: PerspektifKomunikasi, Budaya, dan Sosioteknologi. Bandung: Simbiosa Rekatama Media.

Susanti, S., \& Permana, R.S.M. (2017). Pembelajaran Literasi Budaya Sunda pada Peserta Didik SD Bestari Utami Kabupaten Garut Jawa Barat. Dharmakarya, 6 (2), 106-110.

Ulin, J.C. (2014). The Business of Media Distribution: Monetizing Film, TV, and Video Content. Burlington: Focal Press. 